Proc. Estonian Acad. Sci. Biol. Ecol., 2003, 52, 2, 112-124

\title{
Estonian marine phytobenthos monitoring programme: preliminary results and future perspectives
}

\author{
Georg Martin $^{\mathrm{a} *}$, Kaire Torn ${ }^{\mathrm{a}, \mathrm{b}}$, Jonne Kotta ${ }^{\mathrm{a}}$, and Helen Orav-Kotta ${ }^{\mathrm{a}, \mathrm{c}}$ \\ ${ }^{a}$ Estonian Marine Institute, University of Tartu, Marja 4D, 10617 Tallinn, Estonia \\ ${ }^{\mathrm{b}}$ Institute of Botany and Ecology, University of Tartu, Lai 40, 51005 Tartu, Estonia \\ ${ }^{c}$ Institute of Zoology and Hydrobiology, University of Tartu, Vanemuise 46, 51014 Tartu, Estonia
}

Received 15 April 2002, in revised form 2 July 2002

\begin{abstract}
A phytobenthos monitoring programme has been carried out in Estonian coastal waters since 1995. Monitoring activities include six sea areas representing different sets of environmental conditions and anthropogenic impact. Methods used in the programme are based on internationally accepted techniques developed for the HELCOM COMBINE programme. During the observation period, the most important events described were the decline of the Fucus vesiculosus population in the northern Gulf of Riga and the Väinameri area, which has triggered several changes in phytobenthic communities. A new invertebrate species for Estonian coastal waters, Orchestia cavimana, was described in Küdema Bay in 1999. Its population has remained stable since then. In the nearest future the phytobenthos monitoring programme will be reorganized in connection with the implementation of EU WFD in Estonia and the need to include new sea areas in the monitoring activities.
\end{abstract}

Key words: phytobenthos, monitoring, Baltic Sea.

\section{INTRODUCTION}

A phytobenthos monitoring programme has been carried out in Estonia since 1995. Despite the great number of phytobenthic investigations carried out in Estonian coastal waters (see Trei, 1982 and Martin, 2000 for recent overviews) no regular monitoring activities have been undertaken in previous years. The aim of the current marine phytobenthos monitoring programme is to follow shortand long-term changes in benthic communities of coastal sea areas around the Estonian coastline. Combined with data obtained from other marine monitoring programmes and background information the results of these monitoring activities

\footnotetext{
*Corresponding author, georg@klab.envir.ee
} 
give an opportunity to distinguish between processes connected to human activity and natural variability in the coastal ecosystem. The main target of phytobenthos monitoring is to evaluate the human induced eutrophication but also other aspects such as biodiversity and all kinds of abnormal phenomena are considered.

Monitoring areas were selected to cover the major environmentally "problematic" areas and relevant reference conditions. Hence, the monitoring areas include two areas in the Gulf of Finland (the "problematic" area in Tallinn Bay with the reference area in Eru Bay located $60 \mathrm{~km}$ eastwards); two areas in the Gulf of Riga (the "problematic" area in Pärnu Bay together with the reference area in Kõiguste Bay on the southern coast of Saaremaa Island); one area, located on the western coast of Saaremaa Island, to represent the conditions of the open Baltic Proper; and one area, located near the eastern coast of Hiiumaa Island, to represent the conditions of the inner sea of the West Estonian Archipelago (Fig. 1).

The aim of the current report is to present the results of the phytobenthos monitoring programme in Estonia and to discuss some ways of further improvement of phytobenthos monitoring activities in the context of possible developments concerning the implementation of the EU Water Framework Directive and other relevant issues. Information on the Estonian phytobenthos monitoring programme has been published earlier mainly as yearly overviews in the Estonian language (Kukk \& Martin, 1995a, b; Kukk et al., 1996; Martin \& Kukk, 1996; Martin \& Murumets, 1997).

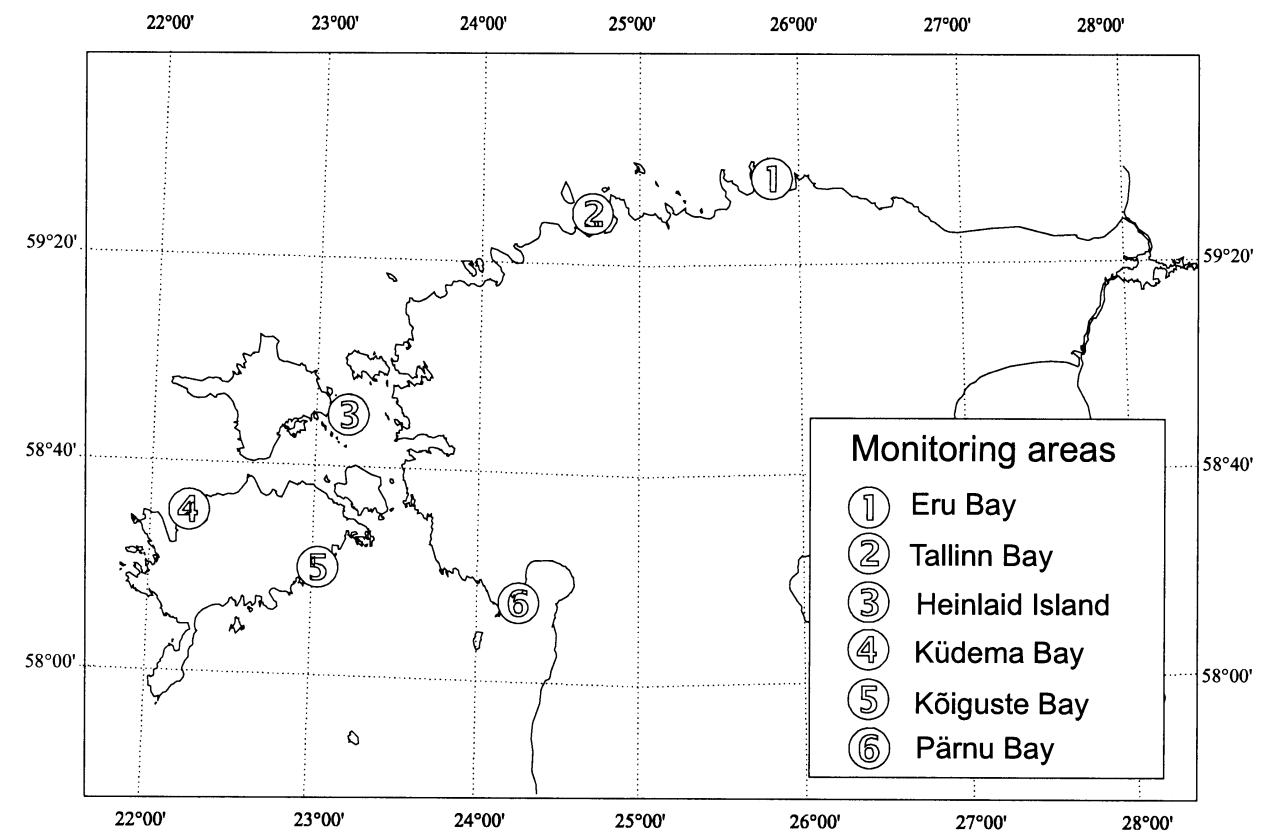

Fig. 1. Location of the phytobenthos monitoring areas along the Estonian coastline. 


\section{MATERIAL AND METHODS}

Monitoring methods

The monitoring methodology used is based on the relevant methods in Scandinavian countries (Kautsky, 1993) and follows phytobenthos monitoring guidelines developed for the HELCOM COMBINE programme in 1999 (Guidelines for Monitoring of Phytobenthic Plant and Animal Communities in the Baltic Sea, http://www.helcom.fi/Monas/CombineManual2/PartC/CFrame.htm).

In the predefined monitoring areas the benthic communities are described on a transect from the water edge to the maximum depth of occurrence of phytobenthic communities once a year during the summer season. SCUBA diving technique is used in depths greater than $1.5 \mathrm{~m}$. Sampling (coverage estimations) is performed within the defined depth intervals, i.e. continuous observations from 0-1.5 m, at larger depth every second metre: $2.5-3.5 \mathrm{~m}, 4.5-5.5 \mathrm{~m}$, etc.). Quantitative samples are taken as three replicates within the predefined depth intervals or within the areas of homogeneous vegetation. In locations lacking vegetation benthic invertebrates are sampled using either a Tvärminne sampler on soft substrate or $20 \times 20 \mathrm{~cm}$ frames for attached bivalves.

In the case of good visibility phytobenthic communities are photodocumented. Quantitative samples are stored in a deep freezer and later sorted in the laboratory. Dry weight is determined after drying the sample at $60^{\circ} \mathrm{C}$ to constant weight.

The monitored parameters include:

- composition of phytobenthos (plants and animals)

- coverage of individual plant and animal species

- total coverage

- depth distribution of phytobenthos species

- depth distribution of algal belts

- biomass (dry weight) distribution of phytobenthic species

For several reasons all the six monitoring areas have not been monitored with the same frequency. Küdema Bay and Kõiguste Bay have been monitored every year (1995-2001). The Tallinn Bay area has been monitored only twice and, therefore, the data are not presented in this report. Other areas have been monitored either four or five times.

\section{Monitoring areas}

The Estonian coastline has a very diverse structure and is influenced by the waters of several sea basins. Three larger basins have been distinguished in the Estonian coastal sea: the Gulf of Finland, the Gulf of Riga, and the Baltic Proper. Besides, the area inside the West Estonian Archipelago has also some specific features. Owing to the differences in the bottom morphology and hydrodynamic conditions, all these basins are characterized by different benthic communities. Moreover, the functional relationships between the anthropogenic pressure and the structure of benthic communities vary between the studied areas. Short descriptions of monitoring areas are given in Table 1. 
Table 1. Description of the marine phytobenthos monitoring areas in Estonian coastal water of the Baltic Sea

\begin{tabular}{|c|c|c|c|c|c|c|}
\hline \multirow[t]{2}{*}{ Area } & Location (WGS84) & \multirow{2}{*}{$\begin{array}{c}\text { Expo- } \\
\text { sure }\end{array}$} & \multirow{2}{*}{$\begin{array}{l}\text { Distance of } 10 \\
\text { (5) } \mathrm{m} \text { isobath } \\
\text { from shore, } \mathrm{m}\end{array}$} & \multirow{2}{*}{$\begin{array}{c}\text { Bottom } \\
\text { composition }\end{array}$} & \multirow{2}{*}{$\begin{array}{l}\text { Surface } \\
\text { water } \\
\text { salinity }\end{array}$} & \multirow{2}{*}{$\begin{array}{l}\text { Human } \\
\text { impact }\end{array}$} \\
\hline & Lat/Lon & & & & & \\
\hline Eru Bay & $59^{\circ} 38.45^{\prime} 25^{\circ} 46.00^{\prime}$ & NE & 400 & $\begin{array}{l}\text { Boulders, } \\
\text { gravel, sand }\end{array}$ & $4.5-6.5$ & Low \\
\hline Tallinn Bay & $59^{\circ} 28.51^{\prime} 24^{\circ} 43.45^{\prime}$ & E & 500 & $\begin{array}{c}\text { Boulders, } \\
\text { sand }\end{array}$ & $5-7$ & High \\
\hline Heinlaid Island & $58^{\circ} 49.80^{\prime} 23^{\circ} 08.60^{\prime}$ & SE & $(2500)$ & $\begin{array}{l}\text { Limestone, } \\
\text { sand }\end{array}$ & $4.5-6$ & Low \\
\hline Küdema Bay* & $58^{\circ} 33.50^{\prime} \quad 22^{\circ} 17.20^{\prime}$ & NW & 400 & $\begin{array}{c}\text { Limestone, } \\
\text { gravel }\end{array}$ & $5-7$ & Low \\
\hline Kõiguste Bay & $58^{\circ} 21.74^{\prime} 22^{\circ} 59.56^{\prime}$ & SSE & 4500 & $\begin{array}{l}\text { Boulders, } \\
\text { gravel, sand }\end{array}$ & $4.5-6$ & Low \\
\hline Pärnu Bay & $58^{\circ} 16.90^{\prime} 24^{\circ} 16.06^{\prime}$ & SE & $(1700)$ & $\begin{array}{l}\text { Boulders, } \\
\text { sand }\end{array}$ & $3.5-4.5$ & High \\
\hline
\end{tabular}

* Upwelling area

Eru Bay, located at the southern shore of the Gulf of Finland, is part of Lahemaa National Park. Its salinity conditions are typical of the central part of the Gulf of Finland. Upwelling events are highly probable. The bottom slope is relatively steep. The depth of $10 \mathrm{~m}$ is reached at a $400-500 \mathrm{~m}$ distance from the shoreline. The monitoring area is located in a hydrologically very active region where strong currents accompanying severe storms can change the structure of seafloor by displacing large amounts of sediment. During the current monitoring programme such changes have been described several times. Human impact and the influence of fresh water are very low. No other marine monitoring activities are carried out in the area.

Tallinn Bay is situated in the southern Gulf of Finland. It extends from the Suurupi Peninsula in the west to the Viimsi Peninsula in the east. An imaginary line connecting the tips of Naissaar, Aegna, and Kräsuli islands forms its northern border. The open part of the bay covers $250 \mathrm{~km}^{2}$ and its maximum depth is $90 \mathrm{~m}$. Naissaar, the sixth largest island of Estonia, is situated in the mouth of Tallinn Bay. A deep trench in the northern part of the bay allows deep water from the Gulf of Finland to enter Tallinn Bay. The salinity in the bay varies between 5.5 and 9.5 PSU. The area is considered to be a "hot spot" because the large urban area of the city of Tallinn and intensive shipping activities of Tallinn harbour influence the nutrient conditions of the coastal waters. The phytobenthos monitoring area is located near the coast in the central part of the bay on the eastern side of the Paljassaare Peninsula. Intensive water quality monitoring activities are carried out in the bay in the frame of the Estonian Marine Monitoring Programme. 
Heinlaid Island is located in the northern part of the Väinameri (inner sea of the West Estonian Archipelago) near the eastern coast of Hiiumaa Island. The sea area around Heinlaid is characterized by shallow waters. Maximum depth in the monitoring area is $5 \mathrm{~m}$. The transect is located in a hydrologically very active sea area. The hydrological front of the Väinameri is described by Suursaar et al. (1998). Numerous subfronts move rapidly over the whole Väinameri area depending on the wind-induced water movement between the Gulf of Riga and the entrance area of the Gulf of Finland. Therefore, the salinity and nutrient regimes are very unstable in this area and depend on the origin of the waters filling the basin. The influence of fresh water is limited to the $1 \mathrm{~km}^{3}$ annually entering the Väinameri area from the Kasari River (Astok et al., 1999). In the monitoring location the seafloor consists of limestone bedrock at a depth of $0-1.5 \mathrm{~m}$, which is replaced by sand deeper down. No other marine monitoring activities are carried out in the area except coastal fish sampling performed on stations located $10 \mathrm{~km}$ westwards during a couple of years.

Küdema Bay is located on the NW coast of Saaremaa Island and is open to the waters of the Baltic Proper. This is an active upwelling area and its salinity as well as nutrient regime are influenced by this phenomenon. The surface water salinity is in the interval of 5-7 PSU. The coastal slope in this area is relatively steep (in the phytobenthos monitoring area $10 \mathrm{~m}$ depth is reached $400 \mathrm{~m}$ from the shoreline). The bottom is dominated by hard substrate composed from limestone bedrock and granite boulders up to a depth of 6-8 m. Deeper the proportion of gravel and some coarse sand is slowly increasing. No direct freshwater influence is present in the monitoring area. The monitoring area is located near the mouth of the bay on the eastern coast. Of other monitoring activities only a coastal fish monitoring programme has been carried out in the area.

Kõiguste Bay is located on the southern coast of Saaremaa Island and belongs to the northern Gulf of Riga. The relatively small elongated bay is divided into the northern sheltered and shallow part and the southern open part. The bottom slope is very gentle (the depth of $20 \mathrm{~m}$ is reached at a distance of $10-15 \mathrm{~km}$ from the shoreline). Salinities in the interval of 4.5-6 PSU have been measured. Bottoms are dominated by stony and gravelly substrates covered in deeper areas by a layer of fine sediment. No direct freshwater discharges are influencing the area. The bay is considered to represent background environmental conditions of the northern Gulf of Riga and therefore it was chosen as the reference area for Pärnu Bay in the phytobenthos monitoring programme. The phytobenthos monitoring area is located on the eastern coast of the bay. No other marine monitoring activities are conducted in the area.

Pärnu Bay is located in the NE part of the Gulf of Riga forming a semienclosed water basin with a surface area of about $700 \mathrm{~km}^{2}$ and a volume of $2 \mathrm{~km}^{3}$. With an annual freshwater input to Pärnu Bay of about $2 \mathrm{~km}^{3}$ the northern part of the bay is strongly influenced by the Pärnu River outflow with typical salinities of 2-3 PSU compared to 5 PSU in the central Gulf of Riga. The southern part is open towards the Gulf of Riga and direct influence of fresh water is small in this 
area. The islands of Kihnu and Manilaid are located in the open part of the bay. The maximum depth of the inner part of the bay is $8 \mathrm{~m}$, and the $10 \mathrm{~m}$ isobath reaches only the longitude of Manilaid Island in the southern part of the bay. The bottom is dominated by fine sand and other finer sediments with a few stony patches occurring sporadically near the coastline at a depth of $0-1.5 \mathrm{~m}$. The area is considered to be a "hot spot" area because of eutrophication caused by the town of Pärnu and the Pärnu River. The phytobenthos monitoring area is located on the western coast of the bay near the tip of the Liu Peninsula. Pärnu Bay is one of the two intensive monitoring areas in the Estonian Marine Monitoring Programme. Three intensive monitoring stations are located inside the bay where traditional water quality parameters are measured together with several biological parameters such as phytoplankton, zooplankton, macrozoobenthos, primary production of phytoplankton, and chlorophyll $a$ concentration.

\section{RESULTS}

\section{Quantitative parameters}

Quantitative proportions of different phytobenthic groups are quite stable in almost all monitored areas with Fucophyceae dominating the communities in all areas except Pärnu Bay. The proportion of Bangiophyta was somewhat higher in Kõiguste Bay over the monitoring period (Fig. 2). The proportions of annual and perennial species are often connected with the stability of environmental conditions (Kautsky et al., 1999). According to this suggestion Eru Bay has the most stable situation and perennial algae form continuously more than $80 \%$ of the phytobenthic biomass there (Fig. 3). In contrast, Pärnu Bay and Heinlaid had almost no perennial vegetation in 2001 and, thus, the state of their phytobenthic communities could be characterized as severely disturbed. The great proportion of annual species in Kõiguste Bay in 1996 reflected the outbreak of ephemeral, filamentous brown algae, which resulted in a decline in the Fucus population in the following years.

\section{Depth distribution of key species and algal belts}

The depth distribution of macroscopic algae and algal belts is supposed to reflect water transparency conditions and the level of pelagic productivity (Kautsky, 1988). In the current monitoring programme special attention is paid to the depth distribution of Fucus vesiculosus and Furcellaria lumbricalis and the algal belts formed by $F$. vesiculosus and red algae. The algal belt usually corresponds to the lower distribution limit of phytobenthos.

The depth distribution of the red algal belt was quite stable in the monitoring areas representing reference conditions (Fig. 4). On the other hand, the depth distribution pattern of $F$. vesiculosus was different in different areas. While the 

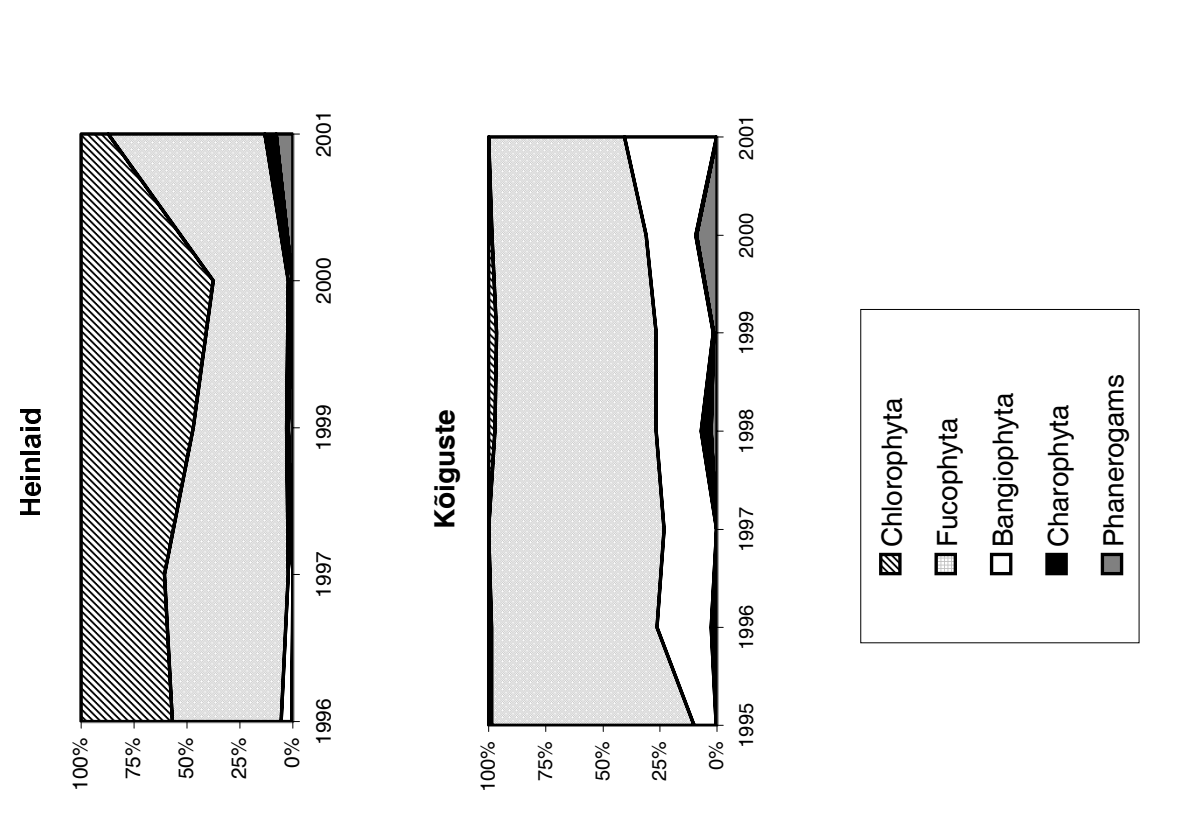

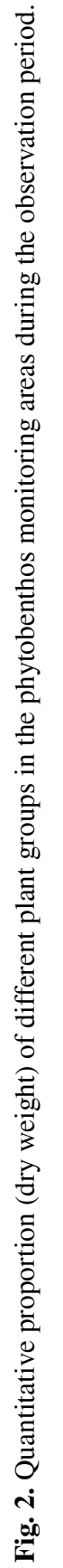



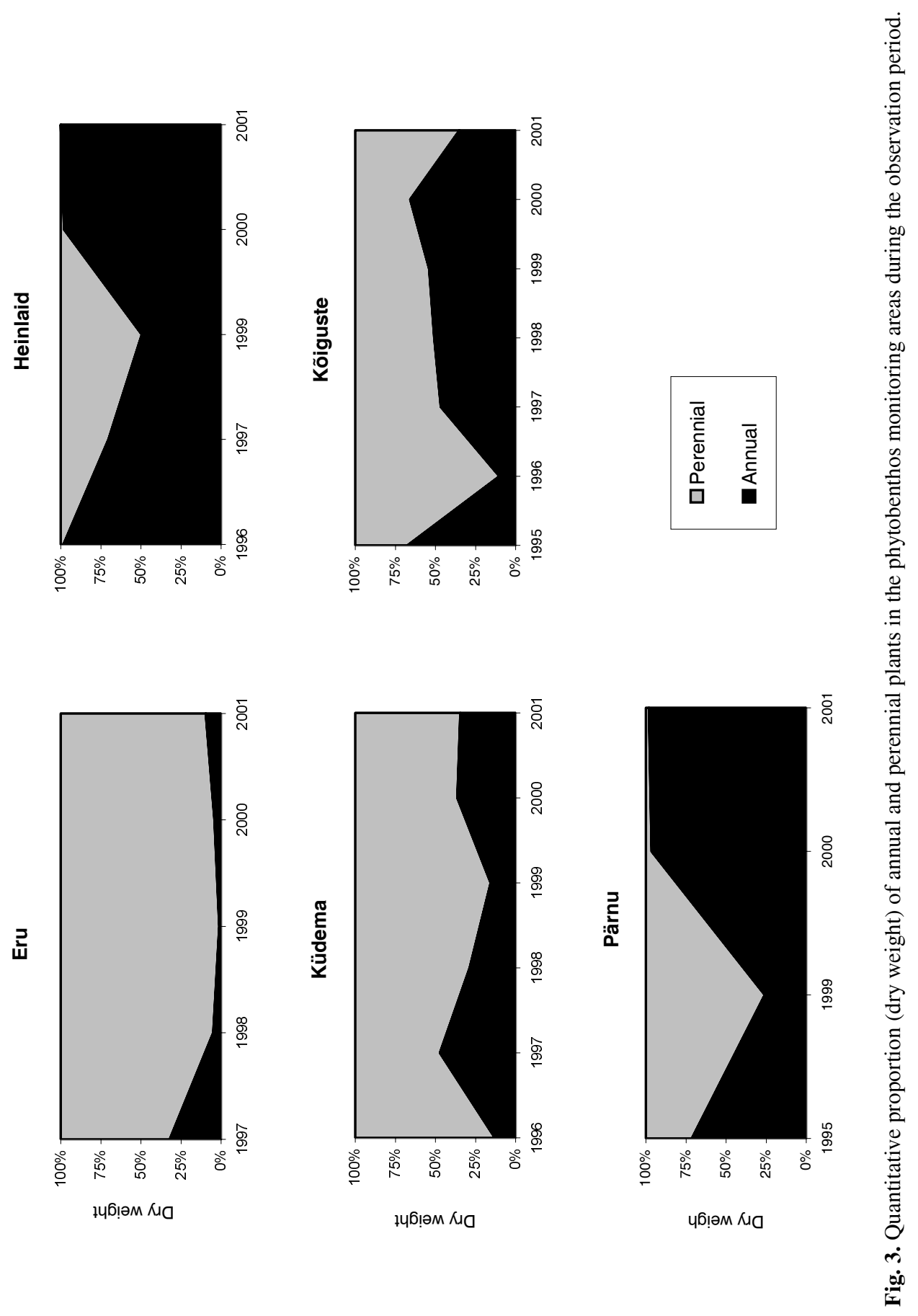

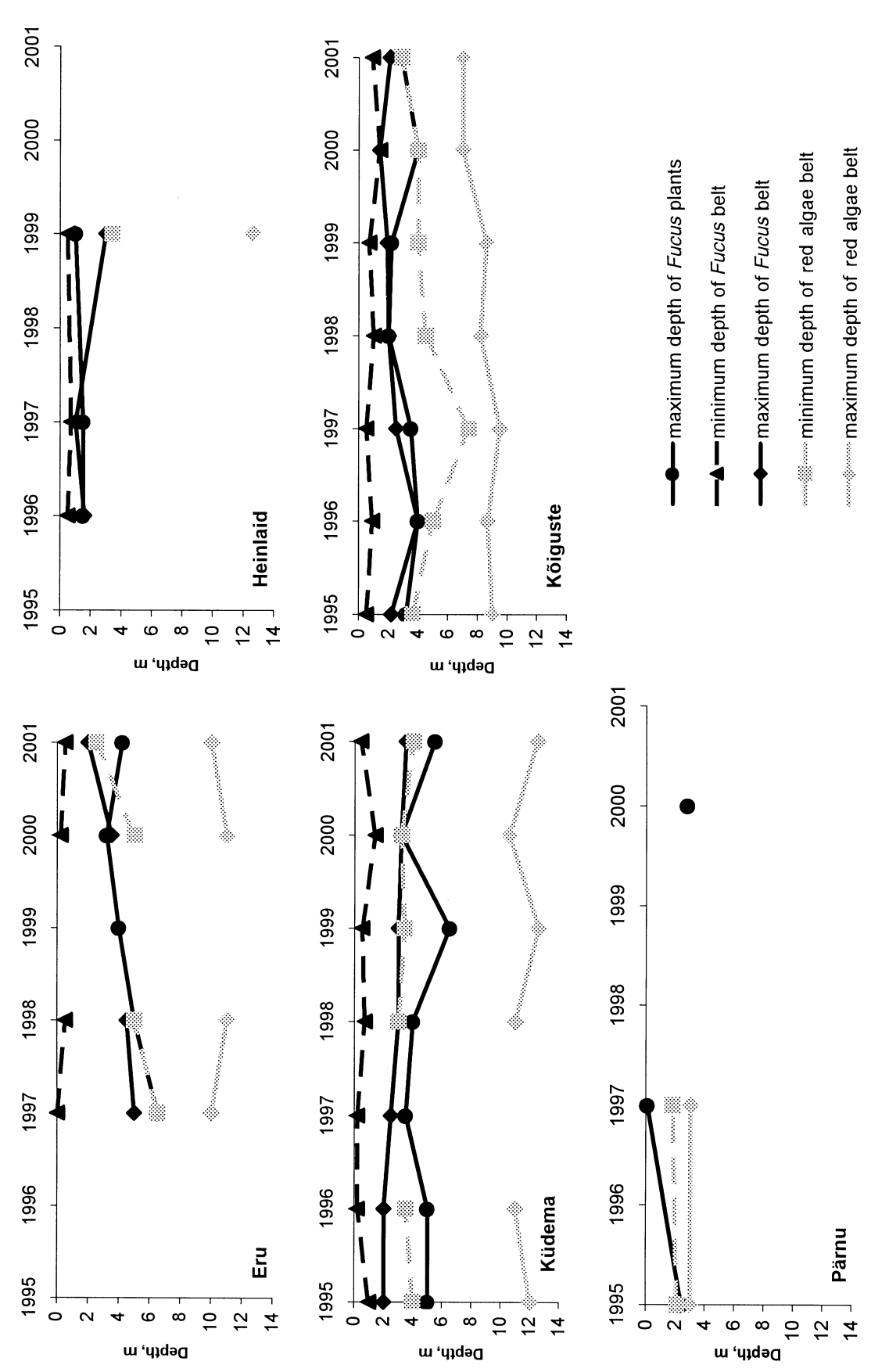

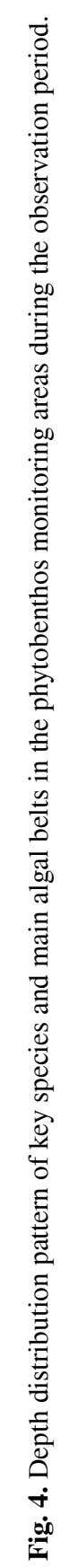


F. vesiculosus belt had small variability in Eru Bay and Küdema Bay during the observation period, then noteworthy changes were observed in Kõiguste Bay and Heinlaid. In Kõiguste Bay the F. vesiculosus belt narrowed continuously since 1997 and almost disappeared in 2000. The same phenomenon was observed in the Heinlaid area where the bladder wrack disappeared after 1999. In Kõiguste Bay the first sings of recovery of the Fucus population were observed in 2001. This event has been described in the literature (Kotta et al., 2000; Martin 2000). The reasons of the Fucus decline in Kõiguste Bay were suggested to be related to the massive outbreak of filamentous, ephemeral macroalgae since 1997.

\title{
Benthic invertebrate populations of the phytobenthic zone
}

In two monitoring areas (Küdema Bay and Kõiguste Bay) the biomass of filter feeders increased during the observation period (Fig. 5). The reasons for these changes are different in the two areas. In Küdema Bay the increase in the biomass of filter feeders is most likely related to the high pelagic productivity caused by intensive upwelling conditions. In Kõiguste Bay the large amount of suspended organic matter in the water is due to decaying filamentous algal biomass.

\section{New benthic species}

A new benthic invertebrate species for Estonian coastal waters was discovered at the Küdema monitoring area in 1999 (Kotta, 2000). This was the amphipod Orchestia cavimana inhabiting $F$. vesiculosus mats washed ashore. This population stayed in a stable condition also during the years 2000 and 2001.

\begin{abstract}
Abnormal events
Two phenomena were described during the present monitoring programme that could be classified as abnormal events. In 1997 an extraordinary mass development of filamentous brown algae, Pilayella littoralis, was recorded in the waters of the West Estonian Archipelago. This phenomenon was described in the Kõiguste Bay, Küdema Bay, and Heinlaid monitoring areas. The areas in the Gulf of Finland and Pärnu Bay were not affected by this event.

Occurrence of filamentous algal mats has deserved special attention in the monitoring programmes carried out in other Baltic Sea countries (Norkko, 1997; Bäck et al., 2000; Lehvo \& Bäck, 2001). During the present monitoring programme an occurrence of filamentous algal mats was recorded twice (in 1997 and 2000) from the Heinlaid monitoring area. In both cases the mats of $P$. littoralis formed mainly at depths of 3-4 m on sandy bottoms and covered the bottom as patches with a diameter of $10-20 \mathrm{~m}$.
\end{abstract}



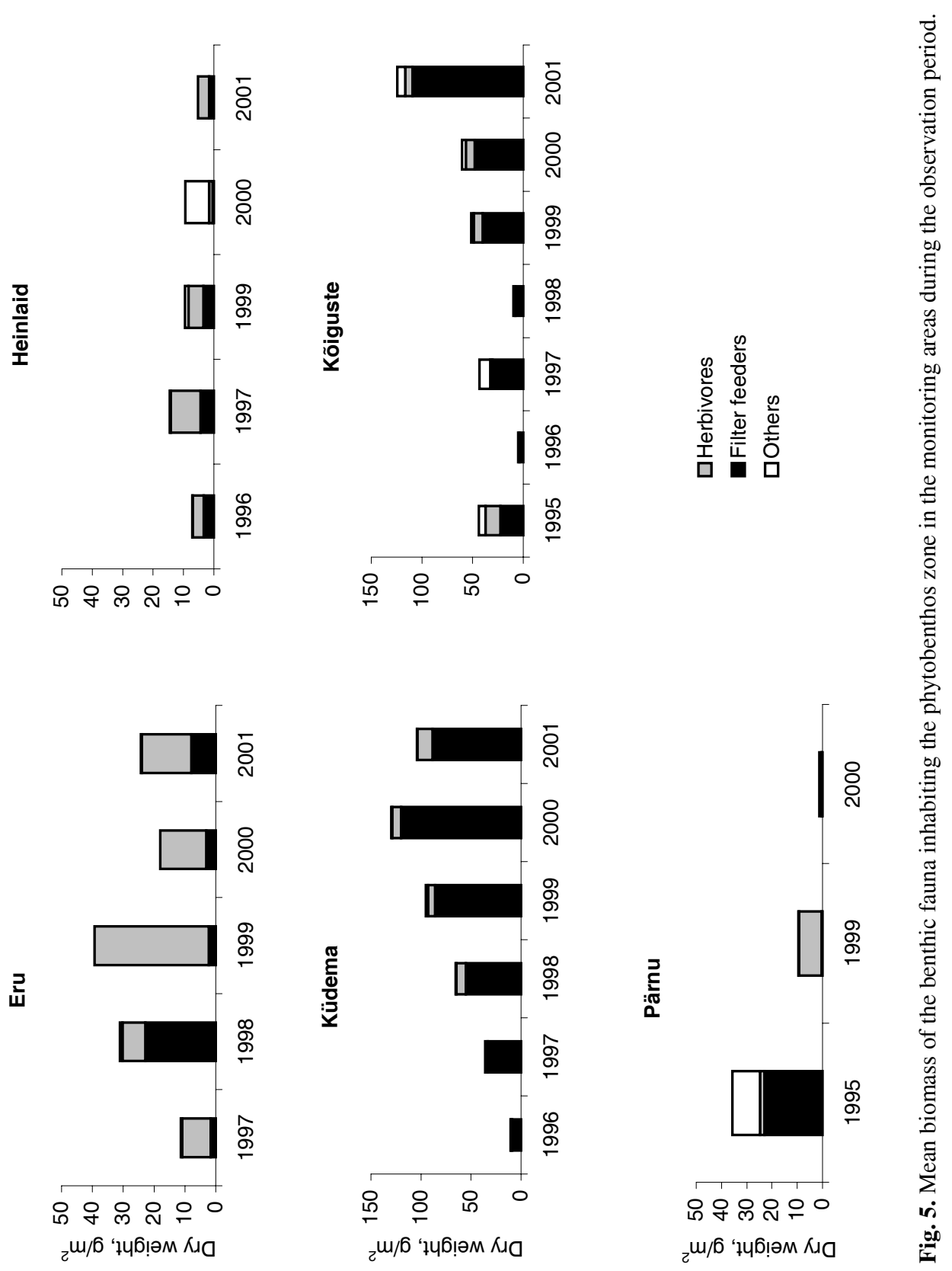


\section{Further development of the monitoring programme}

In the coming years several changes are expected in the phytobenthos monitoring programme in Estonia. Most of these are connected with the implementation of the EU WFD where monitoring of phytobenthos is recommended as a high priority activity in coastal waters. Changes from detailed, costly, and time consuming quantitative monitoring activities towards a more qualitative approach are considered and developed at the present moment.

The application of new techniques, for example underwater video surveillance to enhance the productivity and reduce the costs of the programme, are considered. Including new sea areas such as Narva Bay to the phytobenthos monitoring activities will create the need of introducing new methods. In the case of Narva Bay monitoring of artificial substrate seems to be a promising approach as the area in general lacks suitable hard substrate for phytobenthos growth.

\section{ACKNOWLEDGEMENTS}

The phytobenthos monitoring programme is financed by the Estonian Ministry of the Environment as a subproject of the Estonian Marine Monitoring Programme. This study was also supported by the governmental programme 0182578 s03. Many people have been involved in the activities described in the present report. We want to express our gratitude to Tiina Kapten, Tiina Paalme, Triin Reitalu, Kai Martin, Markus Teeäär, Jaak Timpson, and Tiia Rosenberg, who all have participated either in field work or laboratory studies.

\section{REFERENCES}

Astok, V., Otsmann, M. \& Suursaar, Ü. 1999. Water exchange as the main physical process in semi-enclosed marine systems: the Gulf of Riga case. Hydrobiologia, 393, 11-18.

Bäck, S., Lehvo, A. \& Blomster, J. 2000. Mass occurrence of unattached Enteromorpha intestinalis on the Finnish Baltic Sea coast. Ann. Bot. Fenn., 37, 155-161.

Kautsky, H. 1988. Factors Structuring Phytobenthic Communities in the Baltic Sea. Akademitryck, Edsbruk.

Kautsky, H. 1993. Methods for monitoring of phytobenthic plant and animal communities in the Baltic Sea. In Ecology of Baltic Terrestrial, Coastal and Offshore areas - Protection and Management, pp. 21-59. Gdansk.

Kautsky, H., Martin, G., Mäkinen, A., Borgiel, M., Vahteri, P. \& Rissanen, J. 1999. Structure of phytobenthic and associated animal communities in the Gulf of Riga. Hydrobiologia, 393, 191-200.

Kotta, J. 2000. First record of the talitrid amphipod Orchestia cavimana in the northern Baltic Sea. Proc. Estonian Acad. Sci. Biol. Ecol., 49, 221-224.

Kotta, J., Paalme, T., Martin, G. \& Mäkinen, A. 2000. Major changes in macroalgae community composition affect the food and habitat preference of Idotea baltica. Internat. Rev. Hydrobiol., 85, 693-701. 
Kukk, H. \& Martin, G. 1995a. Merebioloogia. In Keskkonnaseire 1994, pp. 34-37. Keskkonnaministeeriumi Info-Tehnokeskus, Tallinn.

Kukk, H. \& Martin, G. 1995b. Merebioloogia. In Keskkond 1994, pp. 50-53. Keskkonnaministeeriumi Info-Tehnokeskus, Tallinn.

Kukk, H., Martin, G., Jaanus, A., Martin, J., Bogdanov, V., Põllumäe, A., Kotta, I. \& Kotta, J. 1996. Merebioloogia. Eutrofeerumine. In Keskkonnaseire 1995, pp. 70-72. Keskkonnaministeeriumi Info-Tehnokeskus, Tallinn.

Lehvo, A. \& Bäck, S. 2001. Survey of macroalgal mats on southeastern coast of Finland. Aquatic Conserv.: Mar. Freshw. Ecosyst., 11, 11-18.

Martin, G. \& Kukk, H. 1996. Põhjataimestik. In Keskkonnaseire 1995, pp. 86-89. Keskkonnaministeeriumi Info-Tehnokeskus, Tallinn.

Martin, G. 2000. Phytobenthic communities of the Gulf of Riga and the inner sea of the WestEstonian Archipelago. Diss. Biol. Univ. Tartu., 64.

Martin, G. \& Murumets, K. 1997. Põhjataimestiku seire. Eesti Keskkonnaministeerium, Infoleht, 1-2, $11-14$.

Norkko, A. 1997. The role of drifting macroalgal mats in structuring coastal zoobenthos. Ph.D. thesis, Abo Akademi University, Finland.

Suursaar, Ü., Astok, V. \& Otsmann, M. 1998. The front of Väinameri. EMI Rep. Ser., 9, 23-33.

Trei, T. 1982. A Review of Hydrobotanical Investigations in the Waters of the Soviet Baltic (18031980). Tallinn (in Russian).

\title{
Eesti merepõhjataimestiku seire programm: esialgsed tulemused ja tuleviku väljavaated
}

\author{
Georg Martin, Kaire Torn, Jonne Kotta ja Helen Orav-Kotta
}

Merepõhjataimestiku seire programmiga on Eestis tegeldud alates 1995. aastast. Seiret tehakse kokku kuuel alal, mis iseloomustavad erinevaid keskkonnatingimusi ja inimmõju ulatust. Seires kasutatav metodoloogia põhineb rahvusvaheliselt tunnustatud meetoditel, mis on välja arendatud HELCOM COMBINE programmi jaoks. Kõige tähtsamaks vaatlusperioodi jooksul kirjeldatud nähtuseks oli põisadru kadumine Liivi lahe põhjaosast ja Väinamerest. Vaatlustel leiti Eesti vetes uus selgrootu liik Orchestia cavimana. Selle populatsioon püsib Küdema lahes stabiilne alates 1999. aasta suvest. Lähiajal on oodata põhjataimestiku seire programmi ümberkujundamist seoses Euroopa Ühenduse veeraamdirektiivi rakendamisega Eestis. See võib tuua kaasa vajaduse muuta seire metoodikat ja lisada uusi merealasid seiratavate piirkondade hulka. 